\author{
Євтушевська 0.0. \\ кандидат економічних наук, доцент \\ E-mail: olga163alex@gmail.com \\ Хамардюк А.Б. \\ магістрант \\ кафедра обліку та аудиту \\ Одеська національна академія харчових технологій \\ вул. Канатна, 112, м. Одеса, Україна, 65039 \\ E-mail: anna.khamardiuk@gmail.com
}

\title{
ОСОБЛИВОСТІ ОБЛІКУ І АНАЛІЗУ ВИТРАТ ДІЯЛЬНОСТІ НА ПІДПРИЄМСТВАХ ВИНОРОБНОЇ ГАЛУЗІ
}

\begin{abstract}
У статті викладено та розглянуто особливості обліку і аналізу витрат діяльності на підприємствах виноробної галузі, досліджено теоретичні аспекти обліку витрат діяльності, методики аналізу витрат діяльності. Також досліджено особливості обліку витрат діяльності на підприємствах виноробної галузі м. Одеса. Для того, щоб виріс економічний рівень держави та суб'єктів господарювання необхідно, щоб процес виготовлення продукції був ефективним. Об'єктом обліку витрат у виноробній галузі є виноградні культури (або групи культур), витрати на виробництво вина, витрати, що підлягають розподілу, інші витрати.В управлінні витратами найголовніше значення має оперативна інформація отримана про витрати, що дозволяє втручатися в виробничий процес і оптимізувати його.

Ключові слова: облік, витрати, виноробна галузь, операційні витрати, аналіз, собівартість, витрати на збут, адміністративні витрати
\end{abstract}

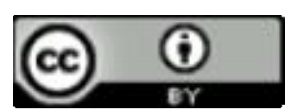

This work is licensed under a Creative Commons Attribution 4.0 International License http://creativecommons.org/licenses/by/4.0/

Постановка проблеми та її зв'язок $з$ важливими науковими та практичними завданнями. При виробництві продукції відбувається планомірне комбінування різних ресурсів виробництва, а саме матеріальних, трудових, технологічних, організаційних та створення нових видів продукції. Саме тому, для того, щоб виріс економічний рівень держави та суб'єктів господарювання необхідно, щоб процес виготовлення продукції був ефективним. Під ефективністю розуміється отримання максимального рівня прибутковості виробництва при мінімальних (оптимальних) витратах ресурсів. Важливою складовою національної економіки України $є$ виробництво продукції виноробства, яке здійснюється відповідно 3 правовими регламентами, визначеними Законом України «Про виноград та виноградне вино».

Аналіз останніх публікацій 3 проблеми. Аналіз останніх досліджень і публікацій дозволяє зробити висновок, що від того наскільки ефективно суб'єкт господарювання буде управляти своїми витратами залежить його розвиток та успіх. Питанням особливостей обліку та аналізу займались такі сучасні вчені як: Кузів М.С., Михайлишин Н.П., Гудзь Н.В., Берестецька О.М., Кондрич В.І, Пласієнко В.Я., Карпенко О. В., Ткаченко Н. М., Мних С.В., Отенко В. І., Іванієнко В. В., Мармуль Л.О. та ін.

Формування цілей дослідження. Сформовано наступні цілі дослідження: розкрити порядок визнання та оцінки в обліку витрат підприємства від- повідно до національних та міжнародних стандартів бухгалтерського обліку, порівняння практики обліку, оцінки, визначення та класифікації витрат за міжнародними та вітчизняними стандартами бухгалтерського обліку; розглянути особливості обліку витрат на підприємствах виноробної галузі.

Виклад основного матеріалу дослідження. На даному етапі розвитку економіки в Україні, промислові підприємства мають відповідати гнучкій політиці та швидко реагувати на будь-які зміни політики. Саме тому, слід виділити одне з най важливіших питань ефективності управління підприємством - облік і контроль витрат діяльності промислового підприємства. Така необхідність у вивченні витрат діяльності промислового підприємства зумовлена тим, що витрати діяльності являються головним резервом збільшення позитивного фінансового результату підприємства.

Витрати є зменшення економічної вигоди у звітному періоді у формі вибуття або використання активів чи збільшення зобов'язань, що зумовлює зменшення власного капіталу підприємства (за винятком розподілу капіталу між учасниками (акціонерами) чи його вилучення) за умови, що ці витрати можуть бути достовірно оцінені. Витрати визнаються в обліку, коли існує ймовірність зменшення майбутніх економічних вигід, пов' язаних із зменшенням активів або зі збільшенням зобов'язань, що може бути вірогідно визначено. Витрати визнаються з урахуванням прин - 
ципу відповідності. Вони включаються до Звіту про фінансові результати у періоді, в якому був визнаний дохід, для отримання якого були здійснені ці витрати [4].

Кузів М.С. у своїй роботі приділяє увагу визначанню сутності витрат виробництва вина, підрахунку собівартості продукції, фактичним витратам. Так, фактична собівартість виноматеріалів включає вартість необроблених матеріалів і витрати з обробки [9].

В свою чергу Кондрич В.І. у своїй праці значну увагу приділяє проблемам обліку витрат на підприємствах виноробної галузі На його думку, для удосконалення обліку витрат та собівартості продукції слід впровадити комп'ютерні інформаційні системи та технології в обліку й звітності [10].

Пласієнко В.Я. визначає у своїй роботі об'єкти обліку витрат, склад витрат виробництва, аналітичний та синтетичний облік витрат і собівартості, документальне оформлення обліку витрат і собівартості. Так на його думки витрати на виробництво класифікують за економічними елементами і статтями витрат [11].

Карпенко О.В. відзначає, що система виробничого обліку - це система обліку, що забезпечує можливість калькулювання та контролю собівартості об'єктів витрат. Значну увагу приділяє калькулюванню собівартості, методам обліку, способам калькулювання [12].

У своєму підручнику Ткаченко Н.М. приділяє увагу питанням обліку витратам діяльності, а саме складу, аналітичному та синтетичному обліку витратам на збут, адміністративним витратам, фінансовим витратам, іншим витратам. Також автор розглядає сутність групування витрат собівартості [12].

Особливу увагу слід приділити теоретичним аспектам аналізу витрат діяльності підприємства. Так, Мних С.В. у своїй роботі розглядає зміст і завдання аналізу витрат діяльності, визнання витрат діяльності. Автор пропонує застосовувати системний, комплексний та кібернетичний підхід до аналізу витрат. Системний підхід включає такі складові: виявлення місця і ролі показників витрат в оцінці досягнутої ефектив- ності виробництва; розробку принципової схеми аналізу на основі класифікації факторів і резервів раціоналізації витрат; визначення методів вимірювання факторів і резервів раціоналізації витрат; встановлення основних напрямів мобілізації виявлених резервів раціонального використання виробничих ресурсів у поточному і перспективному плануванні собівартості [14].

Комплексний підхід означає вивчення об'єктів витрат як системи з погляду формування інформації для прийняття управлінських рішень. Комплексний підхід збігається із системним підходом лише стосовно вивчення окремих аспектів, окремих показників витрат. їх динаміка і прогноз на перспективу не тотожні, коли йдеться про об'єкт аналізу загалом. Кібернетичний підхід передбачає розгляд об'єктів витрат як системи, що складається $з$ елементарних перетворювачів інформації. За цим підходом аналіз підпорядкований цілям синтезу економічної системи та iii вдосконалення, економіко-математичні методи аналізу витрат збігаються із системним дослідженням економіки й управління об'єктом [14].

Отенко В.І. в свою чергу значну увагу приділяє аналізу витрат на виробництво і собівартості продукції. Автор пропонує виконувати аналіз динаміки і структури витрат на виробництво; факторний аналіз витрат на виробництво; аналіз витрат за статтями калькуляції [15].

Підприємства Одеси є основними виробниками виноробних виноматеріалів України. Пропонуємо виконати порівняння особливостей обліку і аналізу витрат діяльності на трьох підприємства: ТОВ «ПТК Шабо», ПрАТ «Одеський коньячний завод» та ПрАТ «Одесавинпром».

У цілому організація обліку витрат діяльності на досліджуваних підприємствах $є$ досить схожою. На даних підприємствах облік витрат діяльності ведеться згідно Н(с)БО 1 ««Загальні вимоги до фінансової звітності»; П(с)БО №16 «Витрати» та Закону України «Про бухгалтерський облік та фінансову звітність в Україні».

У табл. 1 порівняємо рахунки, які використовують підприємства для обліку витрат діяльності.

Таблиця 1

Рахунки для обліку витрат діяльності*

\begin{tabular}{|l|c|c|c|}
\hline \multicolumn{1}{|c|}{ Рахунок } & ТОВ «ПТК Шабо» & $\begin{array}{c}\text { ПрАТ «Одеський } \\
\text { коньячний завод» }\end{array}$ & $\begin{array}{c}\text { ПрАТ «Одесавин- } \\
\text { пром» }\end{array}$ \\
\hline 90 «Собівартість реалізації» & + & + & + \\
\hline 92 «дміністративні витрати» & + & + & + \\
\hline 93 «Витрати на збут» & + & + & + \\
\hline 94 «нші витрати операційної діяльності» & + & - & + \\
\hline 96 «Втрати від участі в капіталі» & - & + & - \\
\hline 97 «нші витрати» & + & + & + \\
\hline 98 «одаток на прибуток» & + & + \\
\hline
\end{tabular}

* Сформовано авторами на підставі даних звітності підприємств

Так, з табл. 1 бачимо, що цілому на усіх підприємствах використовуються одні і ті ж рахунки для обліку витрат діяльності. Відзначимо, що у ПрАТ
«Одесавинпром» не використовується рахунок 98 «Податок на прибуток». 
Зазначені підприємства використовують для обліку витрат діяльності типові документи: договори 3 покупцями, платіжні доручення, акти приймання здачі виконаних робіт, звіти про рух продукції та ін.

Так, у ТОВ «ПТК Шабо» при аналізі витрат діяльності виділяють три етапи: підготовчий, основний та заключний. Для виконання підготовчу етапу слід організувати та скласти план економічного аналізу та аналізу його забезпечення. Основний етап аналізу витрат діяльності включає оцінку матеріалів інформації та аналіз абсолютних та відносних показників. Заключний етап свідчить про кінцеву оцінку проведених розрахунків аналізу.

У ПрАТ «Одеський коньячний завод» виділяють 7 етапів для аналізу витрат діяльності: узагальнюючий аналіз витрат діяльності; аналіз нормативної бази формування витрат підприємства; аналіз витрат за калькуляційними статтями; аналіз витрат за елементами та аналіз кінцевих фінансових результатів зміни витрат діяльності підприємства.
У ПрАТ «Одесавинпром» методика аналізу витрат діяльності включає: аналіз зміни розміру і рівня витрат у цілому по підприємству; аналіз зміни обсягу і рівня витрат щодо окремих статей (елементів), а також за структурою витрат; аналіз зміни обсягу i рівня умовно - змінних і умовно-постійних витрат підприємства; аналіз зміни обсягу, рівня та складу витрат щодо інших кваліфікаційних ознак; кількісна оцінка факторів, що впливають на формування витрат у цілому по підприємству та щодо окремих елементів витрат. Тобто, на досліджених підприємствах методика аналізу витрат діяльності схожа. Різниця полягає у т.ч., що у ПрАТ «Одесавинпром» окрему увагу приділяють аналізу змінних та умовно-постійних витрат.

У табл. 2 виконаємо аналіз порівняння величини витрат діяльності у 2016 р.

Порівняння величини витрат діяльності на підприсмствах виноробної галузі

Таблиця 2

$$
\text { м. Одеси у } 2016 \text { р., тис. грн.* }
$$

\begin{tabular}{|c|c|c|c|c|c|c|}
\hline \multirow[t]{2}{*}{ Витрати } & \multicolumn{2}{|c|}{ ТОВ «ПТК Шабо» } & \multicolumn{2}{|c|}{$\begin{array}{l}\text { ПрАТ «Одеський } \\
\text { коньячний завод» }\end{array}$} & \multicolumn{2}{|c|}{ ПрАТ «Одесавинпром» } \\
\hline & тис. грн. & $\%$ & тис. грн. & $\%$ & тис. грн. & $\%$ \\
\hline Собівартість продукції & 260155 & 54,9 & 456837 & 59,6 & 448198 & 86,8 \\
\hline Адміністративні витрати & 27611 & 5,8 & 33776 & 4,4 & 18426 & 3,6 \\
\hline Витрати на збут & 46536 & 9,8 & 109220 & 14,2 & 23908 & 4,6 \\
\hline Інші операційні витрати & 118591 & 25,0 & 95118 & 12,4 & 9037 & 1,8 \\
\hline Фінансові витрати & 19074 & 4,0 & 67023 & 8,7 & 13881 & 2,7 \\
\hline Інші витрати & 7 & 0,0 & 117 & 0,0 & 2765 & 0,5 \\
\hline Витрати з податку на прибуток & 1611 & 0,3 & 4847 & 0,6 & - & - \\
\hline Всього витрат & 473585 & 100 & 766938 & 100 & 516215 & 100 \\
\hline
\end{tabular}

* Сформовано авторами на підставі даних звітності підприємств

Так, проведений аналіз показує, що основну частку витрат на досліджуваних підприємствах складає собівартість, а саме $54,9 \%$ у ТОВ «ПТК Шабо», $59,6 \%$ - у ПрАТ «Одеський коньячний завод» та
86,8\% у ПрАТ «Одесавинпром». На рис. 1 відобразимо графічну зміну величини витрат на досліджуваних підприємствах.

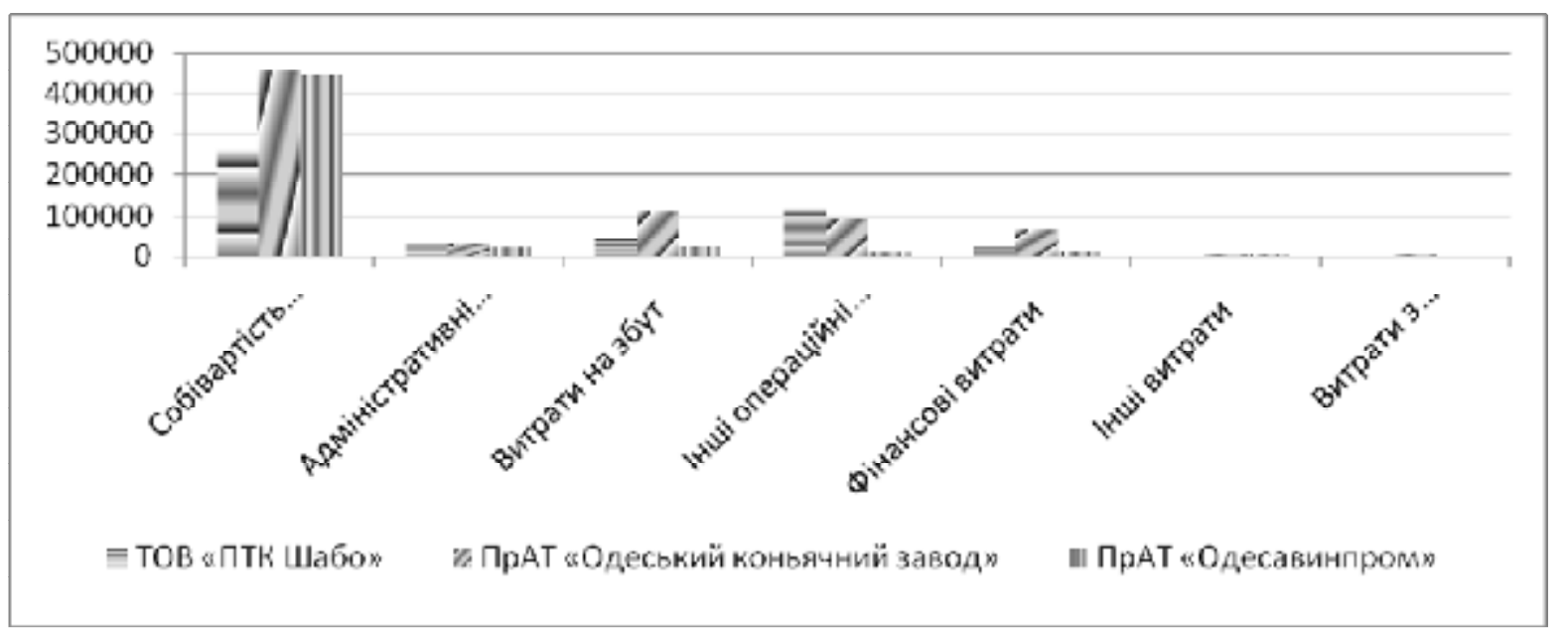

Рис. 1 - Графічна зміна величини витрат*

* побудовано авторами на підставі даних звітності підприємств 
Відзначимо, що частка собівартості продукції $є$ значною та розглядається як позитивний момент діяльності. Відзначимо, що значні частки у ТОВ «ПТК Шабо» займають інші операційні витрати (25\%) та витрати на збут. У ПрАТ «Одеський коньячний завод» - витрати на збут $(14,2 \%)$ та інші опера- ційні витрати (14,2\%), а у ПрАТ «Одесавинпром»адміністративні витрати $(3,6 \%)$ та витрати на збут $(4,6 \%)$.

У табл. 3 порівняємо величину витрат за елементами у 2016 р. на досліджуваних підприємствах.

Таблиця 3

Порівняння величини витрат за елементами на підприсмствах виноробної галузі

м. Одеси у 2016 р., тис. грн.*

\begin{tabular}{|c|c|c|c|c|c|c|}
\hline \multirow[t]{2}{*}{ Витрати } & \multicolumn{2}{|c|}{ ТОВ «ПТК Шабо» } & \multicolumn{2}{|c|}{$\begin{array}{l}\text { ПрАТ «Одеський } \\
\text { коньячний завод» }\end{array}$} & \multicolumn{2}{|c|}{ ПрАТ «Одесавинпром» } \\
\hline & тис. грн. & $\%$ & тис. грн. & $\%$ & тис. грн. & $\%$ \\
\hline Матеріальні затрати & 382728 & 61,5 & 210561 & 50,1 & 348333 & 84,5 \\
\hline Витрати на оплату праці & 29550 & 4,7 & 17101 & 4,1 & 16100 & 3,9 \\
\hline Відрахування на соц. заходи & 10815 & 1,7 & 5210 & 1,2 & 3467 & 0,8 \\
\hline Амортизація & 36096 & 5,8 & 14083 & 3,3 & 7091 & 1,7 \\
\hline Інші операційні витрати & 163611 & 26,3 & 173476 & 41,3 & 37073 & 9,0 \\
\hline Разом & 622800 & 100 & 420431 & 100 & 412064 & 100 \\
\hline
\end{tabular}

* Сформовано авторами на підставі даних звітності підприємств

Аналіз витрат за елементами свідчить про те, що матеріальні затрати на досліджуваних підприємствах займають найбільшу частку, а саме у ТОВ «ПТК Шабо» 61,5\%, у ПрАТ «Одеський коньячний завод»$50,1 \%$ та у ПрАТ «Одесавинпром» - 84,5\%. Відзначимо також про значну частку інших операційних витрат у ПрАТ «Одеський коньячний завод» - 41,3\%.

Висновки і перспективи подальших досліджень. Серед основних проблем обліку витрат підп- риємства на виноробних підприємства є такі проблеми: повноти та своєчасності відображення в системі обліку витрат підприємства; забезпечення максимальної оперативності та достатньої аналітичності вихідної інформації про витрати й доходи підприємства; створення єдиної інформаційної загальнодержавної бази норм і нормативів для обліку й контролю за витратами та доходами підприємства.

\section{Література}

1. Закон України «Про бухгалтерський облік та фінансову звітність в Україні» від16.07.1999 року № 996 - XIV: за станом на 11 червня 2017 p [Електоронний ресурс]. - Режим доступу: http://zakon4.rada.gov.ua/laws/show/996-14.

2. Національне положення (стандарт) бухгалтерського обліку 1 «Загальні вимоги до фінансової звітності» затверджене наказом Міністерства фінансів 07.02.13 №73 : за станом на 14 березня 2017 р. [Електронний pecypc]. - Режим доступу: http://zakon3.rada.gov.ua/laws/show/z0336-13.

3. П(С)БО 16 «Витрати» від 31.12.99 р. № 318 : за станом на 9 серпня 2013 р. [Електронний ресурс]. Режим доступу: http://zakon1.rada.gov.ua/cgi-bin/laws/main.cgi?nreg=z0027-00.

4. Матюха М.М. Шляхи удосконалення бухгалтерського обліку витрат діяльності підприємства / М.М. Матюха // Ефективна економіка. - 2015. - №11. - С.31-32.

5. Грицай О. Удосконалення обліку витрат діяльності промислового підприємства / О. Грицай // Науковий клуб. - 2015. - №2. - С. 45-47.

6. Свтушевська О.О. Теоретичні аспекти впровадження методу бюджетування витрат на виробництво / О.О.Свтушевська // Економіка харчової промисловості. - 2016. - Т.8, Вип. 2. - С. 64-69; DOI: 10.15673/fie.v8i2.132

7. Ромашка О.М. Оцінка та облік витрат за міжнародними стандартами звітності / О.М. Ромашка // Університет економіки та права «КРОК». - 2014. - №5. - С. 198 - 201.

8. Обнявко О.В. Шляхи вдосконалення обліку доходів та витрат у торгівельних підприємствах / О.В. Обнявко // Стан та шляхи удосконалення в галузях економіки. - 2015. - №2. - С. 113-115.

9. Кузів М.С. Облік в галузях промисловості: [навч. посіб.] / М.С. Кузів, Н.П. Михайлишин, Н.В. Гудзь, О.М. Берестецька. - Тернопіль: КРОК, 2013. - 316 с.

10. Кондрич В.І. Особливості галузі виноробства та їх вплив на систему обліку / В.І. Кондрич // Науковий вісник Херсонського державного університету. - 2015. -№12(2). - С. 189-192.

11. Пласієнко В.Я. Бухгалтерський облік у виробничих та агросервісних кооперативах / В. Я. Плаксієнко, Л. О. Мармуль. - К: Центр учбової літератури, 2014. - 448 с.

12. Карпенко О. В. Управлінський облік: [навч. посіб.] / О. В. Карпенко, К. В. Карпенко. - К.: Центр учбової літератури, 2012. - 296 с.

13. Ткаченко Н. М. Бухгалтерський фінансовий облік, оподаткування і звітність: [підруч.] / Н.М. Ткаченко. - [5-те вид. допов. і перероб.]. - К.: Алерта, 2011. - 976 с. 
14. Мних Є.В. Економічний аналіз: [підруч.] / Є.В. Мних. - К. : Знання, 2011. - 630 с.

15. Отенко В. І. Теорія економічного аналізу: [навч. посіб.] / Отенко В. І., Іванієнко В. В.- Х: ВД «ШЖЕК», 2015. - 344 c.

Евтушевская О.А.

кандидат экономических наук, доцент

E-mail: olga163alex@gmail.com

Хамардюк А.Б.

магистрант

кафедра учета и аудита

Одесская национальная академия пищевых технологий

ул. Канатная, 112, г. Одесса, Украина, 65039

E-mail: anna.khamardiuk@gmail.com

\section{ОСОБЕННОСТИ УЧЕТА И АНАЛИЗА ЗАТРАТ ДЕЯТЕЛЬНОСТИ НА ПРЕДПРИЯТИЯХ ВИНОДЕЛЬЧЕСКОЙ ОТРАСЛИ}

В статье изложены и рассмотрены особенности учета и анализа затрат деятельности на предприятиях винодельческой отрасли, исследованы теоретические аспекты учета расходов деятельности, методики анализа затрат деятельности. Также исследованы особенности учета расходов деятельности на предприятиях винодельческой отрасли г. Одессы.

В производстве продукции существует систематическое сочетание различных ресурсов производства, а именно материальных, трудовых, технологических, организационных и создания новых видов продукции. Поэтому для роста экономического уровня государства и субъектов хозяйствования необходимо, чтобы процесс производства продукции был эффективным. Объектом учета затрат в винодельческой отрасли является виноградные культуры (или группы культур), затраты на производства вина, затраты, подлежащие распределению, другие затраты. Синтетический и аналитический учет затрат деятельности ведется на таких счетах как: 90 «Себестоимость реализации», 92 «Административные затраты», 93 «Затраты на сбыт», 94 «Другие затрат операционной деятельности», 96 «Потери от участия в капитале», 97 «Другие затраты», 98 «Налог на прибыль».

К основным заданиям учета затрат деятельности относят: информационное обеспечение администрации предприятия для принятия управленческих решений, наблюдение и контроль за фрактическим уровнем затрат в соотношении с их нормативным и плановым размером; расчет себестоимости произведенной продукции. В управлении затратами самое главное значение имеет оперативная информация получения о затратах, что позволяет вмешиваться в производственный потенциал и оптимизировать его.

Под эффективностью подразумевается получение максимального уровня рентабельности производства при минимальной (оптимальной) стоимости ресурсов. Важным компонентом народного хозяйства Украины является производство винодельческой продукции, которая осуществляется в соответствии с правовыми нормами, установленными Законом Украины «О винограде и винограде».

Ключевые слова: учет, расходы, винодельческая отрасль, операционные расходы, анализ, себестоимость, затраты на сбыт, административные расходы.

Yevtushevska 0.

PhD, Associate Professor

E-mail: olga163alex@gmail.com

Khamardyuk A.

Undergraduate

Department of Accounting and Auditing

Odessa National Academy of Food Technologies

Kanatna str., 112, Odessa, Ukraine, 65039

E-mail: anna.khamardiuk@gmail.com

\section{FEATURES OF ACCOUNTING AND ANALYSIS OF ACTIVITY EXPENDITURE IN VINEYARD COMPANIES}

The article outlines and discusses the specifics of accounting and analysis of the costs of activities at the wine industry enterprises, explores the theoretical aspects of accounting of activity costs, the methodolo- 
gy for analyzing the costs of activity. Also features of the accounting of expenses of activity at the enterprises of a wine-making branch of Odessa are investigated.

In the production of products there is a systematic combination of various production resources, namely, material, labor, technological, organizational ones and creation of new types of products. Therefore, to increase the economic level of the state and business entities, it is necessary that the production process should be effective. The object of accounting for costs in the wine industry is grape crops (or groups of crops), costs for wine production, costs to be allocated, other costs. Synthetic and analytical accounting of activity costs is maintained on such accounts as: 90 "Cost of sales", 92 "Administrative costs", 93 "Sales costs", 94 "Other operating expenses", 96 "Losses from participation in equity", 97 " Other costs ", 98" Income tax".

The main tasks of accounting of the costs of activities include: information support of the administration of the enterprise for making managerial decisions, monitoring and controlling the actual level of costs in relation to their regulatory and planned size; calculation of the cost of production. In the management of costs, the operational information of receipt of costs is of the most important value, which allows you to interfere with the production potential and optimize it.

Efficiency means obtaining the maximum level of profitability of production with a minimum (optimal) cost of resources. The important component of the national economy of Ukraine is the production of wine products, which is carried out in accordance with the legal norms established by the Law of Ukraine "On grapes and grapes." tive costs.

Keywords: accounting, costs, wine industry, operating costs, analysis, cost, sales costs, administra-

\section{References}

1. Zakon Ukrainy «Pro bukhhalterskyi oblik ta finansovu zvitnist v Ukraini» vid 16.07.1999 roku № 996 XIV: Za stanom na 11 chervnia 2017 r. (2018). Retrieved from http://zakon4.rada.gov.ua/laws/show/996-14.

2. Natsionalne polozhennia (standart) bukhhalterskoho obliku 1 «Zahalni vymohy do finansovoi zvitnosti» zatverdzhene nakazom Ministerstva finansiv 07.02.13 №73 : Za stanom na 14 bereznia 2017 r. (2017). Retrieved from http://zakon3.rada.gov.ua/laws/show/z0336-13.

3. P(S)BO 16 «Vytraty» vid 31.12.99 r. № 318 : Za stanom na 9 serpnia 2013 r. (2013). Retrieved from http://zakon1.rada.gov.ua/cgi-bin/laws/main.cgi?nreg=z0027-00.

4. Matiukha, M. M. (2015). Shliakhy udoskonalennia bukhhalterskoho obliku vytrat diialnosti pidpryiemstva. Efektyvna Ekonomika, (11), 31-32.

5. Hrytsai, O. (2015). Udoskonalennia obliku vytrat diialnosti promyslovoho pidpryiemstva. Naukovyi Klub, (2), 45-47.

6. Yevtushevska, O. O. (2016). Teoretychni aspekty vprovadzhennia metodu biudzhetuvannia vytrat na vyrobnytstvo. Ekonomika Kharchovoi Promyslovosti, 8(2), 64-69. doi:10.15673/fie.v8i2.132

7. Romashka, O. M. (2014). Otsinka ta oblik vytrat za mizhnarodnymy standartamy zvitnosti. Universytet Ekonomiky Ta Prava «KROK», (5), 198-201.

8. Obniavko, O. V. (2015). Hliakhy vdoskonalennia obliku dokhodiv ta vytrat u torhivelnykh pidpryiemstvakh. Stan Ta Shliakhy Udoskonalennia v Haluziakh Ekonomiky, (2), 113-115.

9. Kuziv, M. S., Mykhailyshyn, N. P., Hudz, N. V., \& Berestetska, O. M. (2013). Oblik v haluziakh promyslovosti. Ternopil: KROK.

10. Kondrych, V. I. (2015). Osoblyvosti haluzi vynorobstva ta yikh vplyv na systemu obliku. Naukovyi Visnyk Khersonskoho Derzhavnoho Universytetu, (12 (2)), 189-192.

11. Plasiienko, V. Ya., \& Marmul, L. O. (2014). Bukhhalterskyi oblik u vyrobnychykh ta ahroservisnykh kooperatyvakh. K.: Tsentr uchbovoi literatury.

12. Karpenko, O. V., \& Karpenko, K. V. (2012). Upravlinskyi oblik. K.: Tsentr uchbovoi literatury.

13. Tkachenko, N. M. (2011). Bukhhalterskyi finansovyi oblik, opodatkuvannia i zvitnist (5th ed.). K.: Alerta.

14. Mnykh, Ye. V. (2011). Ekonomichnyi analiz. K.: Znannia.

15. Otenko, V. I., \& Ivaniienko, V. V. (2015). Teoriia ekonomichnoho analizu. Xarkiv: VD «ShZhEK». 